\title{
Carbon and Nitrogen Content and Stock in No-Tillage and Crop-livestock Integration Systems in the Cerrado of Goias State, Brazil
}

\author{
Arcângelo Loss ${ }^{1}$, Marcos Gervasio Pereira ${ }^{2}$, Adriano Perin ${ }^{3} \&$ Lúcia Helena Cunha dos Anjos ${ }^{2}$ \\ ${ }^{1}$ Adjunct Professor, Department of Rural Engineering, Universidade Federal de Santa Catarina (UFSC), \\ Florianópolis, SC 88034-000, Brazil \\ ${ }^{2}$ Associate Professor III, Department of Soils, UFRRJ, Seropédica, RJ 23890-000, Brazil. (Sponsored by CNPq) \\ ${ }^{3}$ Professor D3I at the Instituto Federal Goiano, Rio Verde, GO 75901-970, Brazil \\ Correspondence: Arcângelo Loss, Adjunct Professor, Department of Rural Engineering, Center of Agricultural \\ Sciences, UFSC, Florianópolis, SC 88034-000, Brazil. Tel: 55-48-3721-5343. E-mail: \\ arcangeloloss@yahoo.com.br
}

Received: April 11, 2012 Accepted: May 2, 2012 Online Published: July 11, 2012

doi:10.5539/jas.v4n8p96 URL: http://dx.doi.org/10.5539/jas.v4n8p96

Part of the PhD thesis of A. Loss in Soil Science, Postgraduate Course in Agronomy, CPGA-CS, at the Universidade Federal Rural do Rio de Janeiro (UFRRJ), Seropédica, RJ, 23890-000, Brazil

\begin{abstract}
The objective of this study was to evaluate the total organic carbon (TOC) and nitrogen content, and quantify the TOC and nitrogen stocks in land use systems in the Cerrado region of Goiás State, Brazil. A crop-livestock integration system (CLIS) was evaluated - (corn+brachiaria/beans/cotton/soya beans) and a no-tillage system (NTS) - (sunflower/millet/soya beans/corn). The vegetal coverage of the natural Cerrado, adjacent to the NTS and CLIS, was considered as the original soil condition. Soil samples were collected at layer depths of $0.0-10.0 \mathrm{~cm}$, $10.0-20.0 \mathrm{~cm}, 20.0-30.0 \mathrm{~cm}, 30.0-40.0 \mathrm{~cm}, 40.0-50.0 \mathrm{~cm}, 50.0-60.0 \mathrm{~cm}, 60.0-80.0 \mathrm{~cm}$, and 80.0-100.0 cm, in a full random experimental design. The CLIS had higher contents of TOC and N than the NTS up to a level of $30.0 \mathrm{~cm}$. Higher nitrogen stocks were observed in the Cerrado. In the CLIS, higher TOC contents were found up to $30.0 \mathrm{~cm}$ and nitrogen contents up to $20.0 \mathrm{~cm}$. The sum of stocks up to a depth of $100 \mathrm{~cm}$ for TOC and $40 \mathrm{~cm}$ for nitrogen was greater in the CLIS when compared to the NTS. Under the CLIS, the stocks of TOC $(0.0-30.0 \mathrm{~cm})$ and nitrogen $(0.0-20.0 \mathrm{~cm})$ increased in relation to those of the NTS. The CLIS was more efficient in stock accumulation than the Cerrado for the sum of layers $0.0-40.0 \mathrm{~cm}$ and $0.0-60.0 \mathrm{~cm}$.
\end{abstract}

Keywords: Oxisol, $\mathrm{C} / \mathrm{N}$ ratio equilibrium, root system, crop rotation, moderate use pasture

\section{Introduction}

The conversion of crops from a no-tillage system (NTS) into a crop-livestock integration system (CLIS) may result in significant increases in the soil nutrient content, mainly because the integrated system may lead to higher soil organic matter content (SOM). In contrast, more intense cultivation of the soil may result in a higher extraction of nutrients from CLIS areas. Conclusive studies on the changes in the distribution of carbon and nitrogen contents and stocks after the implementation of a CLIS system are scarce (Marchão et al., 2009; Carvalho et al., 2010a; Loss et al., 2011; Anghinoni et al., 2011).

The CLIS has great potential for agricultural use due to the introduction of forage species. In general, forage species accumulate more carbon than crops for human consumption, as the phytomass of the latter is often insufficient for the maintenance of the soil cover (Macedo, 2009; Carvalho et al., 2010b). The CLIS has been used as a means of recovering pastures degraded by overgrazing and low fertility, resulting in improved productivity due to intensified soil use and minimization of native vegetation removal (Landers, 2007; Salton et al., 2008; Gimenez et al., 2009; Ferreira et al., 2011), particularly in the Cerrado morphoclimatic domain.

Because of the climate, the rate of vegetable residue decomposition in the Cerrado is very high, quickly leaving the soil uncovered. These factors rapidly lead to a reduction in the mulch, and later to a less efficient NTS, when compared to the decomposition rate of other morphoclimatic domains such as the Araucaria and Pampas domains 
in southern Brazil. The CLIS becomes fundamental, as its use in association with the poaceae species (brachiaria and pearl millet) intensifies the production of mulch, especially in the dry season. Besides mulch production, other benefits are better use of the soil due to the characteristics of the graminaceae root system, and alterations of the carbon and nitrogen cycles in the soil profile (Loss et al., 2011).

The introduction of crops associated with pastures in the NTS (especially brachiaria), may result in better environmental conditions (due the diversity of this system), such as the flow of nutrients, and other common natural processes that lead to more conservationist agriculture (Carvalho et al., 2010a,b; Ferreira et al., 2011; Anghinoni et al., 2011). The NTS contributes to the increase of carbon and nitrogen stocks in the soil profile, especially when associated with annual crop rotation (Silva et al., 2009; Martins et al., 2009; Boddey et al., 2010). The association of a CLIS with an NTS may result in an even greater accumulation of carbon and nitrogen in the soil profile in comparison with systems not using forage like brachiaria (Souza et al., 2009). However, it is still necessary to obtain a great volume of data on this accumulation pattern for better guidelines on its use in soil management, particularly with soya bean and off-season corn crops in the center-west region of Brazil (Martins et al., 2009; Carvalho et al., 2009). Therefore, this study's hypothesis is that the use of the NTS with moderately intense grazing increases the carbon and nitrogen stocks in soil in relation to the NTS alone. This study aimed to evaluate the total organic carbon (TOC) and nitrogen contents and quantify the TOC and nitrogen stocks in land use systems in the Cerrado region of Goiás State, Brazil.

\section{Material and Methods}

The study was conducted on the Vargem Grande Farm of Agropecuária Peeters, located in Montividiu, Goiás State, Brazil ( $17^{\circ} 21^{\prime} \mathrm{S}$ and $\left.51^{\circ} 28^{\prime} \mathrm{W}\right)$. The area has a well-defined dry season (from May to September) and rainy season (from October to April). Annual rainfall is $1500 \mathrm{~mm}$ and the maximum and minimum temperatures are 30.1 and $17.8^{\circ} \mathrm{C}$, respectively. The soil in the systems evaluated was classified as Oxisol (Soil Survey Staff, 2006) with a clayey texture (Latossolo Vermelho Distrófico; (Embrapa, 2006)). In the mineralogical composition of the clay fraction, gibbsite, kaolinite and hematite stand out.

The original vegetal coverage of the soil was closed canopy Cerrado forest, removed in 1975 to establish pastures (Urochloa decumbens) and then continuously used for 10 years until 1985 (Figure 1).

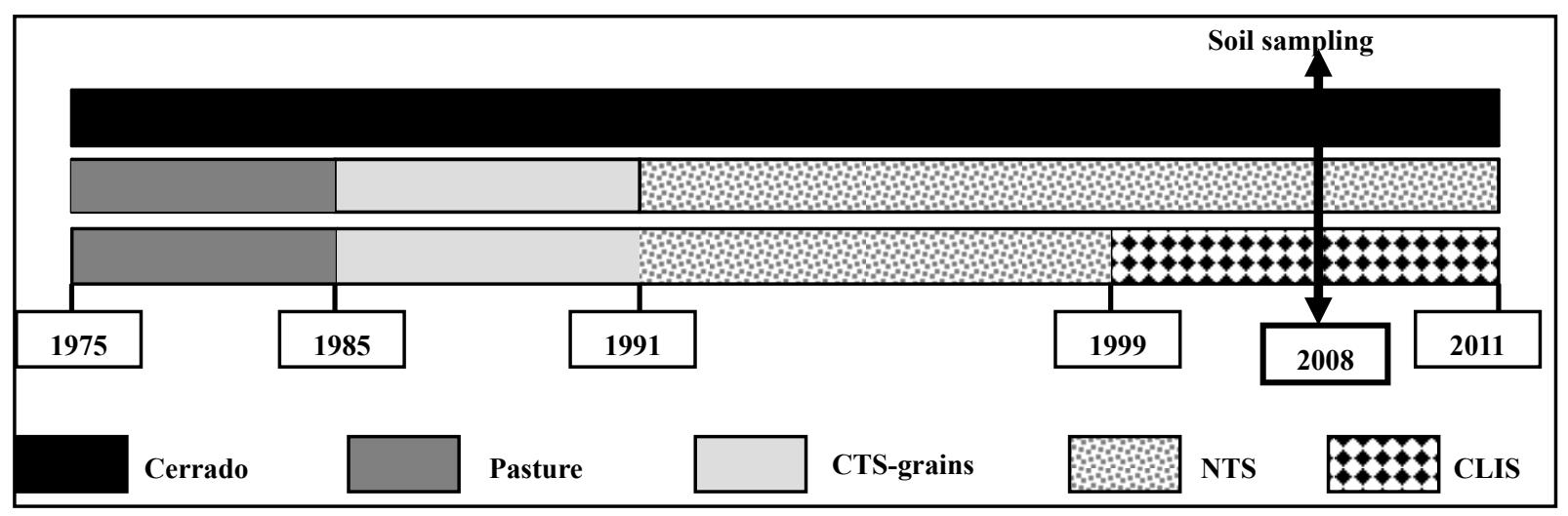

Figure 1. Land use history with implementation dates at the "Vargem Grande" Farm, of Peeters Agriculture and Livestock, located in Montividiu, Goiás State, Brazil (CTS = conventional tillage system, NTS = no-tillage system, CLIS = crop-livestock integration system

The areas were then plowed and harrowed (CTS) until 1991 (7 years) for the cultivation of grains (corn, beans, soya beans and sunflowers). The NTS was implemented with crop rotation-corn, soya beans, cotton, beans (1991-2008) and, from 1999 part of the NTS was transformed into a CLIS (1999-2008). Therefore, the areas evaluated used an NTS with the same crop rotation-NTS only from 1991-2008 and CLIS from 1999-2008 (Figure 1).

The areas evaluated were cultivated using an NTS for 17 years: one with crop rotation only (sunflower-millet-soybean-corn), at coordinates $17^{\circ} 21.12^{\prime} \mathrm{S}, 51^{\circ} 29.46^{\prime} \mathrm{W}$ and altitude of $958 \mathrm{~m}$; and another with brachiaria (U. ruziziensis) intercropped with corn to increase the fodder production in the dry season (corn-brachiaria-beans-cotton-soya beans), at coordinates $17^{\circ} 21.85^{\prime} \mathrm{S}, 51^{\circ} 28.599^{\prime} \mathrm{W}$ and altitude of $859 \mathrm{~m}$. The vegetal coverage of natural Cerrado, adjacent to the cultivated systems $\left(17^{\circ} 26.642^{\prime} \mathrm{S}, 51^{\circ} 22.522^{\prime} \mathrm{W}\right.$, altitude of 951 m) was considered as the original soil condition. 
In the CLIS (corn-brachiaria-beans-cotton-soya beans), corn and brachiaria were planted simultaneously (brachiaria between corn rows). After the corn harvest, cattle were introduced to the system at 2.0 AU per ha (AU-animal unit) for 90 days (July-September). After removal of the cattle, only brachiaria clumps remained. Then, after the first rains, the brachiaria was fertilized with $200 \mathrm{~kg} \mathrm{ha}^{-1}$ of N P K formulation (20-00-20) in the first half of September. After regrowth, when the soil was completely covered by grass, desiccation was done and beans were grown.

Liming was done in the CLIS in July 2005 using a dose of $3.60 \mathrm{Mg} \mathrm{ha}^{-1}$ of dolomitic limestone, with Total Neutralizing Power (TNP) of 70\%, to raise the base saturation to $70 \%$. The same procedure was performed for the NTS, also in July 2005, using a dose of $2.90 \mathrm{Mg} \mathrm{ha}^{-1}$ of dolomitic limestone with TNP of $70 \%$, to raise the base saturation to $60 \%$. The sequence of crops and fertilizers used in both systems from 2002 to 2008 is described in Table 1.

Table 1. Fertilization and cropping sequences used in the evaluated systems of the "Vargem Grande" Farm of Peeters Agriculture and Livestock, located in Montividiu, Goiás State, Brazil

\begin{tabular}{|c|c|c|c|c|}
\hline \multirow{2}{*}{ Year } & \multirow{2}{*}{ Month } & \multirow{2}{*}{ Culture } & \multicolumn{2}{|c|}{ Fertilizer } \\
\hline & & & Crop & Coverage \\
\hline & \multicolumn{4}{|c|}{ CLIS (corn-brachiaria-bean-cotton-soybean) } \\
\hline 2002 & October & Soya beans & $580 \mathrm{~kg} \mathrm{ha}^{-1}$ of $02-20-18$ & ------- \\
\hline 2003 & February & Corn + brachiaria & $500 \mathrm{~kg} \mathrm{ha}^{-1}$ of $07-28-14$ & $100 \mathrm{~kg} \mathrm{ha}^{-1}$ of urea \\
\hline 2003 & October & Soya beans & $580 \mathrm{~kg} \mathrm{ha}^{-1}$ of $02-20-18$ & \\
\hline 2004 & February & Corn + brachiaria & $450 \mathrm{~kg} \mathrm{ha}^{-1}$ of $07-28-14$ & $100 \mathrm{~kg} \mathrm{ha}^{-1}$ of urea \\
\hline 2004 & October & Soyabeans & $500 \mathrm{~kg} \mathrm{ha}^{-1}$ of $02-20-18$ & \\
\hline 2005 & February & Corn + brachiaria & $490 \mathrm{~kg} \mathrm{ha}^{-1}$ of $07-28-14$ & $100 \mathrm{~kg} \mathrm{ha}^{-1}$ of urea \\
\hline 2005 & September & Beans & $400 \mathrm{~kg} \mathrm{ha}^{-1}$ of $05-20-10$ & $90 \mathrm{~kg} \mathrm{ha}^{-1}$ of urea \\
\hline 2005 & December & Cotton & $500 \mathrm{~kg} \mathrm{ha}^{-1}$ of $10-30-10$ & $250 \mathrm{~kg} \mathrm{ha}^{-1}$ of $20-00-20$ \\
\hline 2006 & October & Soya beans & $500 \mathrm{~kg} \mathrm{ha}^{-1}$ of $02-20-18$ & \\
\hline 2007 & February & Corn + brachiaria & $450 \mathrm{~kg} \mathrm{ha}^{-1}$ of $07-28-14$ & $100 \mathrm{~kg} \mathrm{ha}^{-1}$ of urea \\
\hline 2007 & October & Soya beans & $450 \mathrm{~kg} \mathrm{ha}^{-1}$ of $02-20-18$ & \\
\hline 2008 & February & Corn + brachiaria & $450 \mathrm{~kg} \mathrm{ha}^{-1}$ of $07-28-14$ & $100 \mathrm{~kg} \mathrm{ha}^{-1}$ of urea \\
\hline 2008 & September & Beans & $400 \mathrm{~kg} \mathrm{ha}^{-1}$ of $05-20-10$ & $90 \mathrm{~kg} \mathrm{ha}^{-1}$ of urea \\
\hline \multirow[t]{2}{*}{2008} & December & Cotton & $500 \mathrm{~kg} \mathrm{ha}^{-1}$ of $10-30-10$ & $250 \mathrm{~kg} \mathrm{ha}^{-1}$ of $20-00-20$ \\
\hline & \multicolumn{4}{|c|}{ NTS $^{1}$ (sunflower/millet/soya beans/corn) } \\
\hline 2002 & August & Millet & -------- & -------- \\
\hline 2002 & October & Soya beans & $550 \mathrm{~kg} \mathrm{ha}^{-1}$ of $02-20-18$ & $---\cdot$ \\
\hline 2003 & February & Corn & $450 \mathrm{~kg} \mathrm{ha}^{-1}$ of $07-28-14$ & $100 \mathrm{~kg} \mathrm{ha}^{-1}$ of urea \\
\hline 2003 & August & Millet & 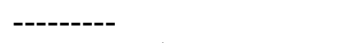 & 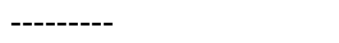 \\
\hline 2003 & October & Soya beans & $550 \mathrm{~kg} \mathrm{ha}^{-1}$ of $02-20-18$ & -------- \\
\hline 2004 & February & Corn & $450 \mathrm{~kg} \mathrm{ha}^{-1}$ of $07-28-14$ & $100 \mathrm{~kg} \mathrm{ha}^{-1}$ of urea \\
\hline 2004 & August & Millet & 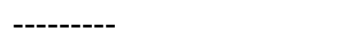 & 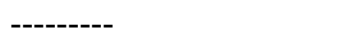 \\
\hline 2004 & October & Soya beans & $550 \mathrm{~kg} \mathrm{ha}^{-1}$ of $02-20-18$ & --------- \\
\hline 2005 & February & Corn & $450 \mathrm{~kg} \mathrm{ha}^{-1}$ of $07-28-14$ & $100 \mathrm{~kg} \mathrm{ha}^{-1}$ of urea \\
\hline 2005 & August & Millet & 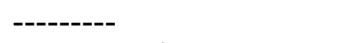 & -------- \\
\hline 2005 & October & Soya beans & $550 \mathrm{~kg} \mathrm{ha}^{-1}$ of $02-20-18$ & \\
\hline 2006 & February & Sunflower & $300 \mathrm{~kg} \mathrm{ha}^{-1}$ of $02-20-20$ & $100 \mathrm{~kg} \mathrm{ha}^{-1}$ of urea \\
\hline 2006 & August & Millet & 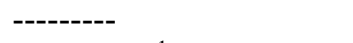 & 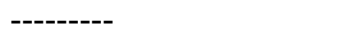 \\
\hline 2006 & October & Soya beans & $500 \mathrm{~kg} \mathrm{ha}^{-1}$ of $02-20-18$ & \\
\hline 2007 & February & Corn & $400 \mathrm{~kg} \mathrm{ha}^{-1}$ of $07-28-14$ & $100 \mathrm{~kg} \mathrm{ha}^{-1}$ of urea \\
\hline 2007 & August & Millet & 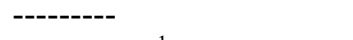 & 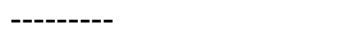 \\
\hline 2007 & October & Soya beans & $500 \mathrm{~kg} \mathrm{ha}^{-1}$ of $02-20-18$ & \\
\hline 2008 & February & Sunflower & $300 \mathrm{~kg} \mathrm{ha}^{-1}$ of $02-20-20$ & $100 \mathrm{~kg} \mathrm{ha}^{-1}$ of urea \\
\hline 2008 & August & Millet & -------- = & -------- \\
\hline 2008 & October & Soybean & $500 \mathrm{~kg} \mathrm{ha}^{-1}$ of $02-20-18$ & --------- \\
\hline
\end{tabular}

${ }^{1}$ For the NTS, in August of each year (2002-2008) millet was planted for fodder production and soya beans were planted in October. Before 2002, off-season and millet crops were not planted and the system remained at rest during May to September, during which plants of the grass family such as guinea grass and brachiaria grew spontaneously. NTS $=$ no-tillage system, CLIS $=$ crop-livestock integration system. 
For soil sampling in March 2008, the NTS was cropped with sunflowers and the CLIS with corn and brachiaria. A $600 \mathrm{~m}^{2}$ section was marked in each system and four trenches were opened crosswise to crop rows for soil sampling at depths of $0.0-10.0 \mathrm{~cm}, 10.0-20.0 \mathrm{~cm}, 20.0-30.0 \mathrm{~cm}, 30.0-40.0 \mathrm{~cm}, 40.0-50.0 \mathrm{~cm}$, $50.0-60.0 \mathrm{~cm}, 60.0-80.0 \mathrm{~cm}$ and $80.0-100.0 \mathrm{~cm}$. Three single samples in each trench were collected to form a composite sample, totaling four replications in each land use system. After collection, the samples were air-dried and sieved with a $2 \mathrm{~mm}$ mesh sieve to obtain air-dried ground soil (ADGS). At the same depths, soil samples were collected to determine bulk density, using the volumetric ring method (Embrapa, 1997). The values obtained were used to calculate the equivalent soil mass and analyze carbon and nitrogen stocks in the soil profile.

The TOC and total nitrogen contents were determined by the dry combustion method in an AutoAnalyzer at $900^{\circ} \mathrm{C}$ (CHN-600 Carlo Erba EA-1110, Italy). TOC and nitrogen stocks were calculated using the equivalent soil mass method (Ellert \& Bettany, 1995; Sisti et al., 2004), as described below:

$$
C_{S}=\sum_{i=1}^{n-1} C_{T i}+\left[M_{T n}-\left(\sum_{i=1}^{n} M_{T i}-\sum_{i=1}^{n} M_{S i}\right)\right] C_{T n}
$$

where:

$C_{s}=$ total stock $\left(\mathrm{Mg} \mathrm{ha}^{-1}\right)$;

$\sum_{i=1}^{n-1} C_{T i}=$ sum of nutrients from the most superficial to the deepest layer of the soil profile evaluated in a specific experimental area $\left(\mathrm{Mg} \mathrm{ha}^{-1}\right)$;

$\sum_{i=1}^{n} M_{T_{i}}=$ sum of soil mass from the most superficial to the deepest layer of the soil profile investigated in a specific experimental area $\left(\mathrm{Mg} \mathrm{ha}^{-1}\right)$;

$\sum_{i=1}^{n} M_{S i}=$ sum of soil mass from the most superficial to the deepest layer of the soil profile sampled as a reference treatment $\left(\mathrm{Mg} \mathrm{ha}^{-1}\right)$; $M_{T_{n}}=$ soil mass in the deepest layer of the soil profile assessed in a specific experimental area $\left(\mathrm{Mg} \mathrm{ha}^{-1}\right)$;

$C_{T_{n}}=$ nutrient level at the deepest layer of the soil profile studied in a specific experimental area (Mg nutrient. $\mathrm{Mg}$ soil $\left.^{-1}\right)$.

The results were analyzed for data normality and homogeneity by means of the Lilliefors and Cochran and Bartlett tests. Later, a completely randomized design with three land use systems (NTS, CLIS and Cerrado) and four replications, was analyzed. The land use systems were evaluated under the same climatic and topographic soil conditions. The results were submitted to variance analysis with application of the F test. The mean values, when significant, were compared with an LSD-student test, at $5 \%$ probability.

\section{Results and Discussion}

\subsection{Distribution of TOC and Nitrogen Contents in the Soil Profile}

In the Cerrado, NTS, and CLIS, the TOC and total nitrogen contents decreased proportionally to the increase in the depth of the soil sample (Figures 2 and 3). This pattern results from the greater input of vegetable residues on the top layer of the soil from rotated crops in the crop systems and from litter in the Cerrado. With a greater deposition of vegetable material, the TOC and nitrogen contents were higher in the surface layers (particularly in the 0.0-10.0 cm layer) in comparison to the deeper layers. These results are similar to those reported by Jantalia et al. (2007); Siqueira et al. (2009) and Costa Junior et al. (2011a \& 2011b) for the TOC and nitrogen dynamics in the soil-plant-atmosphere system with different soil use systems in the Cerrado. 
Total organic carbon $\left(\mathrm{g} \mathrm{kg}^{-1}\right)$

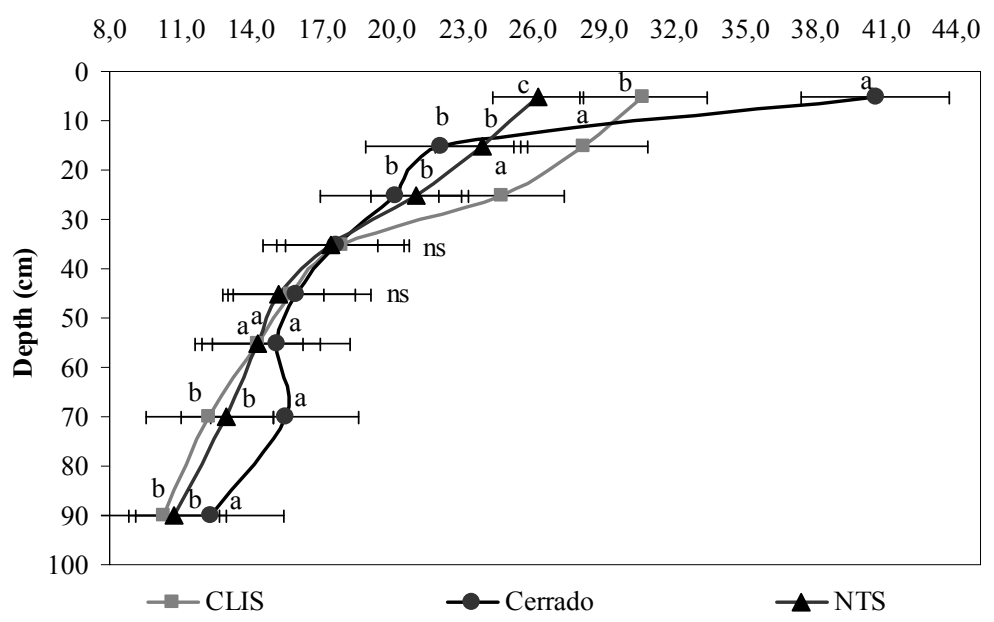

Figure 2. Total organic carbon in soil for land use systems in Montividiu, Goiás State, Brazil. (The error bars indicate the standard error of the mean values for four repetitions). Mean values followed by the same letter do not differ among the systems assessed for each depth, according to the LSD-student test at $5 \%$. ns $=$ not significant in the F test $5 \%$. NTS = no-tillage system; CLIS = crop-livestock integration system

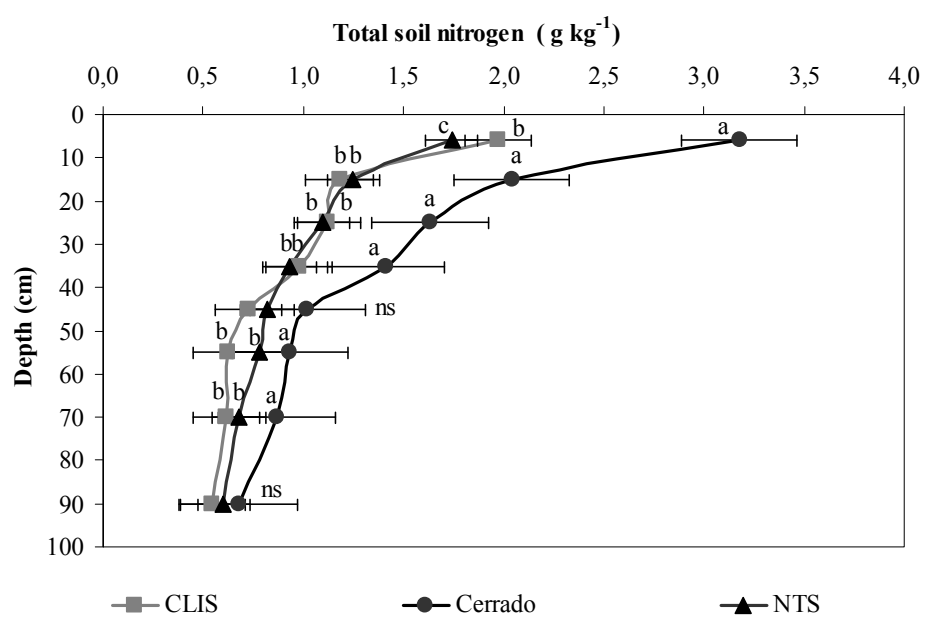

Figure 3. Total soil nitrogen for different land use systems in Montividiu, Goiás State, Brazil. (The error bars indicate the standard error of the mean values for four repetitions). Mean values followed by the same letter do not differ among the systems assessed for each depth, according to the LSD-student test at $5 \%$. ns $=$ not significant by the $\mathrm{F}$ test $5 \%$. NTS = no-tillage system; CLIS = crop-livestock integration system

The highest TOC and nitrogen contents were found in the Cerrado, followed by the CLIS and the NTS, in the $0.0-10.0 \mathrm{~cm}$ layer. The TOC values were $40.54,30.65$ and $26.20 \mathrm{~g} \mathrm{~kg}^{-1}$, in the Cerrado, CLIS and the NTS, respectively (Figure 2). The nitrogen contents were 3.18, 1.85, and $1.65 \mathrm{~g} \mathrm{~kg}^{-1}$, in the Cerrado, CLIS, and NTS, respectively (Figure 3). The high TOC (0.0-10.0 cm layer) and nitrogen contents in the Cerrado result from the constant litter deposition in this area and the greater chemical and physical stability of this system, the original soil condition. The leaf litter deposited in the Cerrado is the most expressive compartment of carbon and nitrogen input when compared with the other soil use systems.

For layer depths between 10.0-20.0 cm and 20.0-30.0 cm, the CLIS had higher TOC contents with no differences between the values of the NTS and Cerrado. Layers $30.0-40.0 \mathrm{~cm}, 40.0-50.0 \mathrm{~cm}$, and 50.0-60.0 cm did not present differences in the systems assessed and the layers below $60.0 \mathrm{~cm}$ in the Cerrado had the greatest TOC contents, with no difference between the NTS and the CLIS (Figure 2).

Among the crop systems, greater TOC $(0.0-30.0 \mathrm{~cm})$ and nitrogen $(0.0-10.0 \mathrm{~cm})$ contents were observed in the CLIS, relative to the NTS. This may be attributed to the use of brachiaria together with off-season corn which 
produces a greater amount of straw, and, therefore, favors the accumulation of carbon and nitrogen due to the soil exploitation by the root system. The use of two leguminosae (soya beans and beans) in the CLIS and only soya beans in the NTS is another factor (Table 1).

It is important to point out that increases in the nitrogen content, by either biological fixation (leguminosae) or nitrogen fertilization, favor the accumulation of carbon in the soil (Bayer \& Mielniczuk, 1997; Urquiaga et al., 2005). According to Pillon et al. (2004), the incorporation of vegetable material through the roots at greater depths of the soil profile is an important strategy for improving the quality of the surface soil and for the accumulation of carbon in the soil. Nitrogen certainly exerts a key role in carbon accumulation, as the TOC does not increase when the nitrogen content is a limiting factor of the biological activity (Urquiaga et al., 2005). This close relationship between the carbon and nitrogen contents was observed in different locations in Brazil for grain crops, Cerrado, and native forest conditions, in soil layers up to $100 \mathrm{~cm}$ deep (Sisti et al., 2004). This corroborates the results found in this study.

At the other depths $(30.0-40.0 \mathrm{~cm}, 40.0-50.0 \mathrm{~cm}$ and $50.0-60.0 \mathrm{~cm})$, the similarity between the TOC contents (absence of differences between the systems) indicates that the crops grown in the NTS and the CLIS for 17 years had the same TOC contents as the original system (Cerrado). However, in layers $60.0-80.0 \mathrm{~cm}$ and $80.0-100.0 \mathrm{~cm}$, the crop systems had not recovered the original Cerrado contents - their TOC values were lower than those of the Cerrado.

The nitrogen content of the Cerrado was higher in all layers, with the exception of layers 40.0-50.0 cm and 80.0-100.0 cm, which did not differ from each other. Among the crop systems, the CLIS had the greatest values only in the $0.0-10.0-\mathrm{cm}$ layer, with no differences for the other studied layers up to $100.0 \mathrm{~cm}$ (Figure 3). The nitrogen values in the CLIS ranged from 1.85 to $0.54 \mathrm{~g} \mathrm{~kg}^{-1}$, while in the NTS the contents ranged from 1.65 to 0.60 $\mathrm{g} \mathrm{kg}^{-1}$. The differences found in the nitrogen contents of the surface soil layer in the crop systems are related to the mineral fertilization used and the use of two leguminosae (soya beans and beans) in the CLIS and soya beans only in the NTS (Table 1).

\subsection{Distribution of Carbon and Nitrogen Stocks in the Soil Profile}

The greatest TOC stocks were found in layers $0.0-10.0 \mathrm{~cm}, 60.0-80.0 \mathrm{~cm}$ and $80.0-100.0 \mathrm{~cm}$ in the Cerrado (Table 2). This pattern for the $0.0-10.0 \mathrm{~cm}$ layer is related to the large deposition of organic matter, which is greater in this area due to the input of vegetable residues (litter) and the absence of anthropic influence. The greater stocks of TOC at deep layers indicate that the original TOC contents of the soil have still not recovered after the removal of the Cerrado for the implementation of the NTS.

Table 2. Total organic carbon stocks $\left(\mathrm{Mg} \mathrm{ha}^{-1}\right)$ in soil for land use systems in Montividiu, Goiás State, Brazil

\begin{tabular}{|c|c|c|c|c|c|c|c|c|}
\hline \multirow{2}{*}{$\begin{array}{l}\text { Soil use systems } \\
\text { Cerrado }\end{array}$} & \multicolumn{8}{|c|}{ Soil Layers (cm) } \\
\hline & $31.06 \mathrm{a}$ & $20.39 \mathrm{c}$ & $19.58 \mathrm{~b}$ & $18.44 \mathrm{a}$ & $18.30^{\mathrm{ns}}$ & $17.57 \mathrm{a}$ & $37.09 \mathrm{a}$ & $29.79 \mathrm{a}$ \\
\hline CLIS & $26.27 \mathrm{~b}$ & $26.25 \mathrm{a}$ & $22.84 \mathrm{a}$ & $19.59 \mathrm{a}$ & $19.26^{\mathrm{ns}}$ & $16.74 \mathrm{a}$ & $29.50 \mathrm{~b}$ & $25.21 \mathrm{~b}$ \\
\hline \multirow[t]{3}{*}{ NTS } & $22.31 \mathrm{c}$ & $22.44 \mathrm{~b}$ & $18.14 \mathrm{~b}$ & $18.62 \mathrm{a}$ & $18.56^{\mathrm{ns}}$ & $16.73 \mathrm{a}$ & $31.32 \mathrm{~b}$ & $26.46 \mathrm{~b}$ \\
\hline & \multicolumn{8}{|c|}{ Sum of Soil Layer Values (cm) } \\
\hline & \multicolumn{2}{|c|}{$0-20$} & \multicolumn{2}{|c|}{$0-40$} & \multicolumn{2}{|c|}{$0-60$} & \multicolumn{2}{|c|}{$0-100$} \\
\hline Cerrado & \multicolumn{2}{|c|}{$51.45 \mathrm{a}$} & \multicolumn{2}{|c|}{$89.47 \mathrm{~b}$} & \multicolumn{2}{|c|}{$125.34 \mathrm{~b}$} & \multicolumn{2}{|c|}{$192.22 \mathrm{a}$} \\
\hline CLIS & \multicolumn{2}{|c|}{$52.52 \mathrm{a}$} & \multicolumn{2}{|c|}{$94.95 \mathrm{a}$} & \multicolumn{2}{|c|}{$130.95 \mathrm{a}$} & \multicolumn{2}{|c|}{$185.66 \mathrm{~b}$} \\
\hline NTS & \multicolumn{2}{|c|}{$44.75 \mathrm{~b}$} & \multicolumn{2}{|c|}{$81.51 \mathrm{c}$} & \multicolumn{2}{|c|}{$116.80 \mathrm{c}$} & \multicolumn{2}{|c|}{$174.58 \mathrm{c}$} \\
\hline
\end{tabular}

Means followed by the same letter in the columns do not differ among systems assessed by the LSD-Student test at $5 \%$. ns $=$ not significant by the F test 5\%. NTS = no-tillage system; CLIS = crop-livestock integration system

Among the crop systems, the greatest TOC stocks were found in the $0.0-10.0 \mathrm{~cm}, 10.0-20.0 \mathrm{~cm}$ and $20.0-30.0 \mathrm{~cm}$ layers of the CLIS. No difference was observed between the systems in layers $30.0-40.0 \mathrm{~cm}, 40.0-50.0 \mathrm{~cm}$ and 50.0-60.0 cm. The other layers did not differ between crop systems (Table 2).

The nitrogen stocks had greater values in all layers of the Cerrado studied. In the cultivated systems, the greatest nitrogen stocks were found in layers $0.0-10.0 \mathrm{~cm}$ and $10.0-20.0 \mathrm{~cm}$, with no differences between layers 20.0-30.0 $\mathrm{cm}, 30.0-40.0 \mathrm{~cm}$ and $80.0-100.0 \mathrm{~cm}$. In the other layers $(40.0-50.0 \mathrm{~cm}, 50.0-60.0 \mathrm{~cm}$ and $60.0-80.0 \mathrm{~cm})$, the NTS had the greatest nitrogen stocks (Table 3). 
Table 3. Total nitrogen stocks $\left(\mathrm{Mg} \mathrm{ha}^{-1}\right)$ in soil for land use systems in Montividiu, Goiás State, Brazil

\begin{tabular}{|c|c|c|c|c|c|c|c|c|}
\hline \multirow{2}{*}{$\begin{array}{l}\text { Soil use systems } \\
\text { Cerrado }\end{array}$} & \multicolumn{8}{|c|}{ Soil Layers (cm) } \\
\hline & $2.83 \mathrm{a}$ & $1.89 \mathrm{a}$ & $1.84 \mathrm{a}$ & $1.64 \mathrm{a}$ & $1.24 \mathrm{a}$ & $1.08 \mathrm{a}$ & $2.08 \mathrm{a}$ & $1.65 \mathrm{a}$ \\
\hline CLIS & $1.65 \mathrm{~b}$ & $1.46 \mathrm{~b}$ & $1.28 \mathrm{~b}$ & $1.09 \mathrm{~b}$ & $0.90 \mathrm{c}$ & $0.73 \mathrm{c}$ & $1.48 \mathrm{c}$ & $1.33 \mathrm{~b}$ \\
\hline \multirow[t]{3}{*}{ NTS } & $1.47 \mathrm{c}$ & $1.29 \mathrm{c}$ & $1.28 \mathrm{~b}$ & $1.13 \mathrm{~b}$ & $1.00 \mathrm{~b}$ & $0.91 \mathrm{~b}$ & $1.64 \mathrm{~b}$ & $1.48 \mathrm{~b}$ \\
\hline & \multicolumn{8}{|c|}{ Sum of Soil Layer Values (cm) } \\
\hline & \multicolumn{2}{|c|}{$0-20$} & \multicolumn{2}{|c|}{$0-40$} & \multicolumn{2}{|c|}{$0-60$} & \multicolumn{2}{|c|}{$0-100$} \\
\hline Cerrado & \multicolumn{2}{|c|}{$4.72 \mathrm{a}$} & \multicolumn{2}{|c|}{$8.20 \mathrm{a}$} & \multicolumn{2}{|c|}{$10.52 \mathrm{a}$} & \multicolumn{2}{|c|}{$14.25 \mathrm{a}$} \\
\hline CLIS & \multicolumn{2}{|c|}{$3.11 \mathrm{~b}$} & \multicolumn{2}{|c|}{$5.48 \mathrm{~b}$} & \multicolumn{2}{|c|}{$7.11 \mathrm{~b}$} & \multicolumn{2}{|c|}{$9.92 \mathrm{~b}$} \\
\hline NTS & \multicolumn{2}{|c|}{$2.76 \mathrm{c}$} & \multicolumn{2}{|c|}{$5.17 \mathrm{c}$} & \multicolumn{2}{|c|}{$7.08 \mathrm{~b}$} & \multicolumn{2}{|c|}{$10.02 \mathrm{~b}$} \\
\hline
\end{tabular}

Mean values followed by the same letter in the columns do not differ among the systems assessed by the LSD-Student test at $5 \%$. ns $=$ not significant by the F test $5 \%$. NTS $=$ no-tillage system; CLIS $=$ Crop-livestock integration system.

The greatest TOC and nitrogen stocks in the CLIS may be attributed to the use of brachiaria which provides slower degrading crop residues, and, therefore, favors the accumulation of carbon due to its greater $\mathrm{C} / \mathrm{N}$ ratio, in addition to the effect under the surface of the root system's expansion and renewal, which adds carbon and nitrogen to the soil profile. These carbon and nitrogen contents are physically protected inside aggregates that are highly stable in water due to iron and aluminum oxides (Bayer et al., 2000) which form highly stable aggregates (Loss et al., 2011) with carbon and nitrogen occluded on the inside (Beare et al., 1994; Roscoe et al., 2001). The use of brachiaria to intensify the production of straw in the dry season, associated with grazing of 2 animals/ha, probably led to a better mass ratio between the roots and the exposed parts in the CLIS, in comparison to the NTS, and, in turn, to an increase in the TOC and nitrogen contents. These results corroborate those found by Dieckow et al. (2005) for TOC and nitrogen stocks in NTS for a period of 17 years in southern Brazil.

The beneficial effect of the CLIS with adequate grazing intensity, results from the better mass ratio between the roots and exposed parts, which accumulates over time due to the minimal agitation of the soil, and, therefore, little mechanical incorporation of vegetable residues and reduced oxidation. Thus, carbon and nitrogen accumulate on the surface and at depth, the increase in the carbon and nitrogen stocks in the CLIS being related to the transportation of vegetable residues from the surface of the soil by the macro and mesofauna which are greater in integrated systems in relation to single systems (Anghinoni et al., 2011).

The NTS areas have been cultivated for an average of 17 years and are considered to be in the phase of soil system evolution, with the NTS cultivation time as the consolidation phase (10 to 20 years of NTS use) according to (Anghinoni, 2007). In this phase, straw and SOM accumulate, the cation-exchange capacity of the soil increases, more water is stored, and nutrients are recycled. The CLIS had higher values of TOC and nitrogen than the NTS in the surface layers (up to $30.0 \mathrm{~cm}$ for TOC and $20.0 \mathrm{~cm}$ for nitrogen) as well as for the sum of the layers (up to 100 $\mathrm{cm}$ for TOC and $40.0 \mathrm{~cm}$ for nitrogen). This result indicates the efficient accumulation of TOC and nitrogen stocks in the CLIS which is more efficient than crop rotation with brachiaria absent.

In cultivated systems, the absence of soil agitation, crop rotation and the permanence of crop residues on the soil surface, favors aggregation and affords greater protection to the organic matter (Salton et al., 2008), and, consequently, an increase in the TOC and nitrogen stocks.

For nitrogen stocks, only the 40.0-50.0 cm, 50.0-60.0 cm and 60.0-80.0 cm layers in the NTS had greater stocks than the CLIS. The crop systems produce annual crops and one off-season crop, while off-season crops in the NTS have been used only in the last five years. Before that, after the corn crop, the system was left to rest and taken over by invading crops such as guinea grass and brachiaria. Pearl millet also has an effect, as it is sown in August so that soya beans can be sown in October (Table 1). The death of the roots of these graminaceae that have deep root systems, adds nitrogen to the soil, resulting in greater nitrogen stocks in the NTS layers mentioned above in comparison to the CLIS.

The TOC and nitrogen stock values found in layers $0.0-40.0 \mathrm{~cm}$ (94.95 and $81.51 \mathrm{Mg} \mathrm{ha}^{-1}$ for TOC, and 5.48 and $5.17 \mathrm{Mg} \mathrm{ha}^{-1}$ for nitrogen) for CLIS and NTS, respectively; and in the $0.0-100.0 \mathrm{~cm}$ layer $(185.66$ and $174.58 \mathrm{Mg}$ $\mathrm{ha}^{-1}$ for TOC, and 9.92 and $10.02 \mathrm{Mg} \mathrm{ha}^{-1}$ ) for CLIS and NTS, respectively; are greater than those found by Jantalia et al. (2007), with the exception of the TOC stock in the NTS at $0.0-40.0 \mathrm{~cm}$. The authors evaluated the dynamics 
of the TOC and nitrogen stocks in an Oxisol (Latossolo Vermelho) in Planaltina in Brazil's Federal District (also in a Cerrado and NTS environment), with the following crop rotations: corn, soya beans, pearl millet (NTS1) and the same previous rotation, but associated with Andropogon gayanus grass (NTS2). The TOC stock values found by Jantalia et al. (2007) were $84 \mathrm{Mg} \mathrm{ha}^{-1}$ for NTS1 and NTS2 at 0.0-40.0 cm depth, and 139 and $143 \mathrm{Mg} \mathrm{ha}^{-1}$ for NTS1 and NTS2 at 0.0-100.0 cm depth. For the nitrogen stocks, values of 4.9 and $5.1 \mathrm{Mg} \mathrm{ha}^{-1}$ at $0.0-40.0 \mathrm{~cm}$ depth, for NTS1 and NTS2 were found; and 8.2 and $8.5 \mathrm{Mg} \mathrm{ha}^{-1}$ for NTS1 and NTS2 at 0.0-100.0 cm depth.

The results found followed the pattern observed by Jantalia et al. (2007). The authors observed greater TOC and nitrogen stocks in the NTS with Andropogon gayanus grass as a cover plant together with crop rotation, being similar in the CLIS with brachiaria and off-season corn.

The TOC stock values for layers $0.0-40.0 \mathrm{~cm}$ and $0.0-60.0 \mathrm{~cm}$ were compared. The CLIS presented greater TOC stocks than the Cerrado, and in the $0.0-100.0 \mathrm{~cm}$ layer, the opposite pattern was observed (Table 2). These results also show the importance of the study of the TOC stocks up to a depth of $100.0 \mathrm{~cm}$, considering that the layers must have regular thickness intervals (like $10 \mathrm{~cm}$ ), so that the effect of the crop systems can be observed for the sum of the layers. In this study, the CLIS had greater TOC stocks than the original soil condition (Cerrado) at depths up to $60.0 \mathrm{~cm}$. If the study had presented the sum of the layers up to $100.0 \mathrm{~cm}$ deep alone $(0.0-100.0 \mathrm{~cm})$, the effect of the CLIS would have been weakened at deeper layers when compared to the Cerrado.

Among the crop systems, the greatest TOC stocks in the CLIS may result from the use of crop rotation. This may have a positive effect in the nitrogen equilibrium (soya beans, beans, and chemical fertilization), which, in turn, is related to the carbon input, allowing the joint incorporation of these elements for the SOM (Sisti et al., 2004; Urguiaga et al., 2005; Jantalia et al., 2007). This pattern was observed in the present study, with greater nitrogen stocks in layers $0.0-20.0 \mathrm{~cm}$ and $0.0-40.0 \mathrm{~cm}$ for the CLIS (Table 3) in association with greater TOC stocks in these layers (Table 2). These results indicate that the content of organic nitrogen in soil cannot be increased without there being a corresponding increase in the TOC content, and vice-versa, as reported by Urguiaga et al. (2005) in a study on agricultural systems for carbon sequestration in tropical and subtropical environments.

The association of the CLIS and NTS with moderate grazing combines the absence of soil rotation and high vegetable residue input from the use of crops and pastures (Anghinoni et al., 2011; Loss et al., 2011). This pattern also supports the greater TOC $(0.0$ to $30.0 \mathrm{~cm}$, Table 2$)$ and nitrogen $(0.0$ to $20.0 \mathrm{~cm}$, Table 3$)$ stocks found in the CLIS in relation to the area with no pasture (NTS). After 17 years of use of the soil with a conservationist system, using only the NTS from 1991 to 1999 and a CLIS from 1999 to 2008 (Figure 1), the TOC stocks had recovered (resilience), reaching the same values in the NTS, CLIS and Cerrado, at depths of 30.0-40.0 cm, $40.0-50.0 \mathrm{~cm}$, and 50.0-60.0 cm, and greater values in the CLIS for depths of 10.0-20.0 cm and 20.0-30.0 cm (Table 2).

The results observed in the present study are similar to those from some studies in Brazilian tropical and subtropical conditions with the increasing use of grass mulching for the formation of soil coverage, resulting in differentiated input of crop residues in relation to pure systems of grain production, both at the surface and in the soil profile (Souza et al., 2009, 2010; Loss et al., 2011).

As such, it is possible to conclude that CLIS management over time and under the no-till system in conditions of moderate grazing ( 2 animals per hectare), promotes lower outputs of carbon and nitrogen from microbial respiration (Souza et al., 2010) and grazing. As a consequence, the stocks of these elements in soil tend to be greater, as shown in Tables 2 and 3.

\section{Conclusions}

The use of the CLIS with corn+brachiaria/beans/cotton/soya beans under moderate grazing ( 2 animals/ha) increased the stocks of TOC $(0.0-30.0 \mathrm{~cm}$ and for the sum of the layers up to a depth of $100.0 \mathrm{~cm})$ and of nitrogen $(0.0-20.0 \mathrm{~cm}$ and for the sum of the layers up to a depth of $40.0 \mathrm{~cm})$ when compared to the NTS with sunflower/pearl millet/soya beans/corn. The CLIS is more efficient in TOC stock accumulation than the Cerrado for layers $10.0-20.0 \mathrm{~cm}$ and $20.0-40.0 \mathrm{~cm}$ and for the sum of the layers $0.0-40.0 \mathrm{~cm}$ and $0.0-60.0 \mathrm{~cm}$.

\section{Acknowledgements}

To the Agrisus Foundation for funding the research project, to CNPq and FAPERJ for granting the PhD scholarship to the first author, to the Post-graduation Program in Agronomy - Soil Science (CPGA-CS) for their assistance and to Dr. Adriano Perin and colleagues for their help in collecting soil samples for this study.

\section{References}

Anghinoni, I., Moraes, A., Carvalho, P. C. F., Souza, E. D., Conte, O., \& Lang, C. R. (2011). Benefícios da integração lavoura-pecuária sobre a fertilidade do solo em sistema plantio direto. In Fonseca, A. F., Caires, 
E. F., Barth, G. Fertilidade do solo e nutrição de plantas no sistema plantio direto. AEACG/Inpag: Ponta Grosa, p.1-31.

Anghinoni, I. (2007). Fertilidade do solo e seu manejo no sistema plantio direto. In Novais, R.F., Alvarez V., V. H, Barros, N. F., Fontes, R. L. F., Cantarutti, R. B., Neves, J. C. L. (Org.). Fertilidade do Solo. $1^{\text {a }}$ ed. Viçosa: Sociedade Brasileira de Ciência do Solo, v.1, p.873-928.

Bayer, C., Mielniczuck, J., Amado, T. J. C., Martin-Neto, L., \& Fernandes, S. V. (2000). Organic matter storage in a sandy clay loam Acrisol affected by tillage and cropping systems in southern Brazil. Soil Tillage Research, 54, 101-109. http://dx.doi.org/10.1016/S0167-1987(00)00090-8.

Bayer, C., \& Mielniczuk, J. (1997). Nitrogênio total de um solo submetido a diferentes métodos de preparo e sistemas de cultura. Revista Brasileira de Ciência do Solo, 21, 235-239.

Beare, M. H., Cabrera, M. L., Hendrix, P. F., \& Coleman, D. C. (1994). Aggregate-protected and unprotected organic matter pools in conventional-and no-tillage soils. Soil Science Society of America Journal, 58, 787-795. http://dx.doi.org/10.2136/sssaj1994.03615995005800030021x.

Boddey, R., Jantalia, C. P., Conceição, P. C. E., Zanatta, J. A., Mielniczuk, J., Dieckow, J., ... Alves, B. J. R. (2010). Carbon accumulation at depth in Ferralsols under zero-till subtropical agriculture. Global Change Biology, 16, 784-795. http://dx.doi.org/10.1111/j.1365-2486.2009.02020.x

Carvalho, J. L. N., Cerri, C. E. P., Feigl, B. J., Píccolo, M. C., Godinho, V. P., \& Cerri, C. C. (2009). Carbon sequestration in agricultural soils in the Cerrado region of the Brazilian Amazon. Soil Tillage Research, 103, 342-349. http://dx.doi.org/10.1016/j.still.2008.10.022

Carvalho, J. L. N., Raucci, G. S., Cerri, C. E. P., Bernoux, M., Feigl, B. J., Wruck, F. J., \& Cerri, C. C. (2010a). Impact of pasture, agriculture and crop-livestock systems on soil C stocks in Brazil. Soil Tillage Research, 110, 175-186. http://dx.doi.org/10.1016/j.still.2010.07.011.

Carvalho, P. C. F., Anghinoni, I., Moraes, A., Souza, E. D., Sulc, R. M., Lang, C. R., ... Bayer, C. (2010b). Managing grazing animals to achieve nutrient cycling and soil improvement in no-till integrated systems. Nutrient Cycling in Agroecosystems, 88(2), 259-27. http://dx.doi.org/0.1007/s10705-010-9360-x

Costa Junior, C., Piccolo, M. C., Siqueira Neto, M., Camargo, P. B., Cerri, C. C., \& Bernoux, M. (2011a). Carbono total e ${ }^{13} \mathrm{C}$ em agregados do solo sob vegetação nativa e pastagem no bioma cerrado. Revista Brasileira de Ciência do Solo, 35(5), 1241-1252. http://dx.doi.org/10.1590/S0100-06832011000400017

Costa Junior, C., Siqueira Neto, M., Piccolo, M. C., \& Camargo, P. B. (2011b). Nitrogênio e abundância natural de ${ }^{15} \mathrm{~N}$ em agregados do solo sob diferentes usos da terra no Bioma Cerrado. Ensaios e Ciência, 15, 47-66. http://www.sare.unianhanguera.edu.br/index.php/rensc/article/.../1255

Dieckow, J., Martin Neto, L., Milori, D. M. P., Conceição, P. C., Bayer, C., \& Mielniczuk, J. (2005). Sistemas de Preparo do Solo e Características Espectroscópicas da Matéria Orgânica em Ambientes Tropicais e Subtropicais Brasileiros. Boletim de Pesquisa e Desenvolvimento. Embrapa Intrumentação Agropecuária, 12, 1-16. http://www.cnpdia.embrapa.br/publicacoes/download.php?file=BPD12

Ellert, B. H., \& Bettany, J. R. (1995). Calculation of organic matter and nutrients stored in soils under contrasting management regimes. Canadian Journal Soil Science, 75, 529-538. http://dx.doi.org/10.4141/cjss95-075.

Embrapa. (2006). Empresa Brasileira de Pesquisa Agropecuária. Centro Nacional de Pesquisa de Solos. Sistema Brasileiro de Classificação de Solos. Rio de Janeiro: Embrapa Solos, p. 306.

Embrapa. (1997). Empresa Brasileira de Pesquisa Agropecuária. Centro Nacional de Pesquisa Agropecuária de Solos (Rio de Janeiro). Manual de Métodos de análise de solo. $2^{\mathrm{a}}$ ed. Rio de Janeiro, p. 212.

Ferreira, E. V. O., Anghinoni, I., Andrighetti, M. H., Martins, A. P., \& Carvalho, P. C. F. (2011). Ciclagem e balanço de potássio e produtividade de soja na integração lavoura-pecuária sob semeadura direta. Revista Brasileira de Ciência do Solo, 35, 161-169. http://dx.doi.org/10.1590/S0100-06832011000100015

Gimenes, M. J., Dal Pogetto, M. H. F. A., Prado, E. P., \& Souza, R. S. C. E. F. C. (2009). Integração $\begin{array}{lllll}\text { lavoura-pecuária-breve } \quad \text { revisão. } & \text { Revista } & \text { Trópica, } & 4, & 52 .\end{array}$ http://www.periodicoseletronicos.ufma.br/index.php/ccaatropica/.../84/62

Jantalia, C. P., Resck, D. V. S., Alves, B. J. R., Zotarelli, L., Urquiaga, S., \& Boddey, R. M. (2007). Tillage effect on C stocks of a clayey oxisol under a soybean-based crop rotation in the Brazilian Cerrado. Soil Tillage Research, 95, 97-109. http://dx.doi.org/10.1016/j.still.2006.11.005 
Landers, J. N. (2007). Tropical crop-livestock systems in conservation agriculture: the Brazilian experience. Integrated Crop Management, 5, 1-92. http://www.fao.org/ag/AGP/AGPC/doc/Newpub/landers/landers.htm

Loss, A., Pereira, M. G., Anjos, L. H. C., Giacomo, S. G., \& Perin, A. (2011). Agregação, carbono e nitrogênio em agregados do solo sob plantio direto com integração lavoura-pecuária. Pesquisa Agropecuária Brasileira, 46(10), 1269-1276. http://dx.doi.org/10.1590/S0100-204X2011001000022

Macedo, M. C. M. (2009). Integração lavoura e pecuária: o estado da arte e inovações tecnológicas. Revista Brasileira de Zootecnia, 38, 133-146. http://www.scielo.br/pdf/rbz/v38nspe/v38nspea15.pdf

Marchao, R., Becquer, T., Brunet, D., Balbino, L., Vilela, L., \& Brossard, M. (2009). Carbon and nitrogen stocks in a Brazilian clayey Oxisol: 13-year effects of integrated crop livestock management systems. Soil Tillage Research, 103, 442-450. http://dx.doi.org/10.1016/j.still.2008.11.002

Martins, M. R., Cora, J. E., Jorge, R. F., \& Marcelo, A. V. (2009). Crop type influences soil aggregation and organic matter under no-tillage. Soil Tillage Research, 104, 22-29. http://dx.doi.org/10.1016/j.still.2008.11.003.

Pillon, C. N., Mielniczuk, J., \& Martin Neto, L. (2004). Ciclagem da matéria orgânica em sistemas agrícolas.

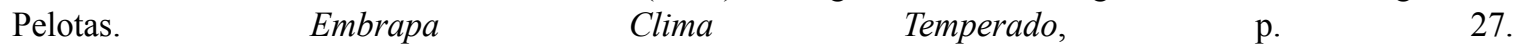
http://www.cpact.embrapa.br/publicacoes/download/documentos/documento_125.pdf

Roscoe, R., Buurman, P., Velthorst, E. J., \& Vasconcellos, C. A. (2001). Soil organic matter dynamics in density and particle size fractions as revealed by the $13 \mathrm{C} / 12 \mathrm{C}$ isotopic ratio in a Cerrado Oxisol. Geoderma, 4 , 185-202. http://dx.doi.org/10.1016/S0016-7061(01)00080-5

Salton, J. C., Mielniczuk, J., Bayer, C., Boeni, M., Conceição, P. C., Fabricio, A. C., Macedo, M. C. M., \& Broch, D. L. (2008). Agregação e estabilidade de agregados do solo em sistemas agropecuários em Mato Grosso do Sul. Revista Brasileira de Ciência do Solo, 32, 11-21. http://dx.doi.org/10.1590/S0100-06832008000100002

Silva, A. A., Galon, R., Galon, L., Ferreira, F. A., Tirloni, S. P., Ferrreira, E. A., Silva, A. F., \& Agnes, E. L. (2009). Sistema de plantio direto na palhada e seu impacto na agricultura brasileira. Revista Ceres, 56, 496-506. http://www.ceres.ufv.br/CERES/revistas/V56N004_01509.pdf

Siqueira Neto, M., M. Piccolo, M. C., Scopel, E., Costa Jr, C., Cerri, C. C., Bernoux, M. (2009). Carbono total e atributos químicos com diferentes usos do solo no Cerrado. Acta Scientiarum. Agronomy, 31, 709-717. http://dx.doi.org/10.4025/actasciagron.v31i4.792

Sisti, C. P. J., Santos, H. P., Kohhann, R., Alves, B. J. R., Urquiaga, S., \& Boddey, R. M. (2004). Change in carbon and nitrogen stocks in soil under 13 years of conventional or zero tillage in southern Brazil. Soil Tillage Research, 76, 39-58. http://dx.doi.org/10.1016/j.still.2003.08.007

Souza, E. D., Carneiro, M. A. C., Paulino, H. B., Silva, C. A., \& Buzetti, S. (2010). Soil aggregation in a crop-livestock integration system under no-tillage. Revista Brasileira de Ciência do Solo, 34, 1365-1374. http://redalyc.uaemex.mx/src/inicio/ArtPdfRed.jsp?iCve=180215875033.

Soil Survey Staff. (2006). Keys to soil taxonomy. 10 ed. USDA-SCS, Washington. p. 332.

Souza, E. D., Costa, S. E. V. G. A., Anghinoni, I., Carvalho, P. C. F., Andrigueti, M., \& Cao, E. (2009). Estoque de carbono orgânico e de nitrogênio no solo em sistema de integração lavoura-pecuária em plantio direto, submetidos a intensidades de pastejo. Revista Brasileira de Ciencia do Solo, 33, 1829-1836. www.scielo.br/pdf/rbcs/v33n6/a31v33n6.pdf

Urquiaga, S., Jantalia, C. P., Zotarelli, L., Alves, B. J. R., \& Boddey, R. M. (2005). Manejo de sistemas agrícolas para o seqüestro de carbono no solo. In AQUINO, A. M., ASSIS, R. L. (Org.). Conhecimentos e Técnicas Avançadas para o Estudo dos Processos da Biota no Sistema Solo-Planta. Brasília: Embrapa, 257-273. 